\title{
DER ER EN SÆRLIG PLADS I HELVEDE FOR DOVNE BØRN
}

Moderne medicin er fast forankret i overbevisningen om, at sundhed er en form for givet udgangspunkt: en normativ tilstand, som kan genoprettes ved at besejre sygdom, der forstås som en abnormitet. (Shildrick 17, min oversættelse).

Denne artikel undersøger, hvordan et computerspils forsøg på at oplyse unge om sundhedsrisici bliver til et disciplinerende værktøj i form af en affektiv fortælling om døden, der på den ene side skaber 'korrekte', 'sunde' og 'levedygtige' subjektpositioner, mens andre forståelser af, hvad sundhed er, på den anden side dømmes ude.

I 2008 udgav Hjerteforeningen, ${ }^{1}$ i samarbejde med Danmarks Pædagogiske Universitetsskole og Copenhagen Business School, rapporten Unge Hjerter. Rapporten er udarbejdet på baggrund af fokusgruppeinterviews med 8. klasses elever fra udvalgte skoler i Danmark og beskriver elevernes viden og kompetencer i forbindelse med sundhed generelt og

1 Hjerteforeningen er en privat sygdomsbekæmpende organisation med 136.500 medlemmer. Foruden at varetage hjertekar-patienters interesser over for beslutningstagere og sundhedsvæsen yder foreningen hvert år økonomisk støtte til danske forskning på hjertekar-området. Læs mere her: www.hjerteforeningen.dk 
hjertekarsygdomme i særdeleshed. I 2010 udgav Hjerteforeningen så undervisningsmaterialet af samme navn baseret på rapportens resultater. Undervisningsmaterialet er tiltænkt børn og unge på 7.-9. klassetrin og omfatter bl.a. computerspillet Life Calculator, men også eksempelvis to korte dokumentarfilm om rygning og fedme. I forordet til rapporten slås det fast, at formålet med at skabe indblik i unges opfattelser af sundhed er at skabe "[...] et bedre fundament for at tilrettelægge sundhedsfremmende og forebyggende indsatser" (Unge hjerter 5). Med sit tydelige og primære formål at oplyse om forebyggelse og risikohåndtering kan spillet Life Calculator betegnes som et sundhedspolitisk tiltag forankret i en biomedicinsk sundhedsforståelse, der lidt forenklet definerer sundhed som fraværet af sygdom (Land og Pedersen 51). Faren ved denne forholdsvis snævre sundhedsforståelse er, at begrebet sundhed let bliver til en både stabil og målbar størrelse, der underbygger en neoliberal tro på, at den enkelte ved hjælp af mere og 'bedre' viden vil være i stand til at afværge sygdom og lidelse, hvis ellers viljen er stor nok (Land og Pedersen; Rose). Ved hjælp af Foucaults biopolitiske begrebsapparat ønsker jeg at problematisere denne sundhedsforståelse og spørge, hvilke kroppe som (u)muliggøres gennem spillets fortælling om særligt sundhed. Inspireret af affektteoretiker Sara Ahmed og hendes teoretisering af følelser som performative og 'klistrende', men også af hendes tanker omkring, hvilke kroppe, der overhovedet tæller som 'sorgbare' og værdifulde, er jeg ligeledes optaget af, hvordan spillets sundhedslogikker og forhandlinger af liv og død kommer i stand.

Skønt det kunne være interessant at undersøge målgruppens refleksioner og reaktioner på spillet, samt den eventuelle påvirkning spillet har på brugeren, er dette ikke målet med artiklen. Jeg sigter i stedet på at skrive fortællinger og forestillinger om den 'usunde' krop frem i et kulturanalytisk perspektiv med særligt fokus på, hvordan sundhedsfremmende fortællinger kan siges at (re)producere forestillinger om kropslig normativitet.

\section{BIOMAGTENS POLITIK}

Foucault sporer samfundets transformation fra det feudale til det kapitalistiske og moderne ved hjælp af sit begreb biomagt (2009, 2011). Biomagtens fineste opgave blev (og er) at kultivere og organisere subjektets liv ned i 
mindste detalje - ved at disciplinere kroppen og regulere befolkningen - i et forsøg på at skabe sunde, raske, levedygtige og ikke mindst føjelige kroppe (Foucault, Seksualitetens historie 149-150). Logikken, der ligger implicit i biomagten, er, at disciplineringen af den enkelte krop tjener samfundets samlede 'legeme' og sundhed:

En sådan form for magt [biomagten] må forsøge at kvalificere, måle, vurdere, hierarkisere, snarere end at vække opsigt med sin morderiskhed; den søger ikke at trække en skillelinje mellem de lydige undersåtter og suveræne fjender, den fremkalder inddelinger, hvis midtpunkt er normen. (Ibid. 149).

Dette anderledes greb om livet og den kolossale mængde ny viden om kroppen, som især lægevidenskaben genererede, tjente til etableringen af moderne normer og rammer for kropslighed. Normer der samtidig betød, at en lang række af 'afvigende' kroppe såsom de syge, de fattige, de kriminelle, de åndssvage og de handicappede (og senere de tykke) blev underlagt heftig kontrol og undersøgelser. Formålet var at 'kurere' kroppen for de fejl og mangler, den måtte have sammenlignet med den ikke-mærkede krop, som nu udgjorde normens absolutte midtpunkt. At tro at kun den 'afvigende' krop blev og er underlagt kontrol er imidlertid en fejl. Biomagt må helt omvendt forstås som en overordnet forståelsesramme, inden for hvilken subjektet ved at inkorporere sig heri kan blive genkendelig som et subjekt og i dette tilfælde: som et sundt, ansvarsfuldt og samfundsnyttigt et af slagsen. Når der derfor lægges op til, at borgeren i højere grad end tidligere bør tage ansvar for egen sundhed, er det derfor ikke (nødvendigvis) en bevægelse væk fra biomagtens greb om livet. Snarere vidner dette element af selvovervågning om, at liv er gennemsyret af den selvdisciplinering, som biomagten sigter på at regulere subjektet gennem. Biomagtens implementering på samtlige af livets niveauer har derfor også betydet, at sundhed i langt højere grad end tidligere forstås som noget dybt personligt forbundet med individuelle valg og private valg (Rose; Lupton; From; Minkler). Interessen for den historiske udvikling, som lægevidenskaben har undergået, er drivkraften bag den kritiske sundhedsforsker Deborah Luptons forsøg på at spore de ændrede forestillinger om folkesundhed, som biopolitikken har medført: 
Siden begyndelsen af det enogtyvende århundrede har folkesundheden været stærkt optaget af at kontrollere kroppe, men har bevæget sig bort fra det at begrænse smitsomme sygdomme til at formane folk om at tage ansvar for opretholdelsen af den personlige kropslige sundhed. Moderne folkesundhed rettet mod "sundhedsfremme" indsnævrer sit fokus på individet ved at knytte de såkaldte livsstilssygdomme med individuel adfærd. (Lupton 35, min oversættelse).

Sociolog Nikolas Rose ser også en ændring i den måde, hvorpå sundhedspolitik historisk set ellers har handlet "[...]om fødselsrater, og dødsrater, om sygdomme og epidemier, om kontrol med vand, kloakering, fødevarer, gravpladser og om livskraften hos dem, der blev stuvet sammen i byer og storbyer" (Rose 27). Ligesom Lupton henter Rose sine værktøjer i Foucaults begrebsapparat og kalder den 'biologiske borgers' nutidige forsøg på at kontrollere, administrere, forvalte og modulere sine livsevner ned i detaljen for en politik om livet selv (Ibid. 28). Ditte-Marie From forklarer på samme vis i sin afhandling Sunde overvægtige børn, hvordan en lignende borger i de teoretiske perspektiver omkring biopædagogik optræder i form af

[...] den dydige bio-borger, der henviser til opkomsten af en helt ny menneskeart: Borgeren, der udviser et ansvar for egen og dermed det fælles samfunds sundhed ved at vise, at han eller hun er i stand til at træffe de rigtige sundhedsvalg (24).

Tilsammen danner Luptons, Roses og Froms Foucault-inspirerede analyser billedet af en moderne, selvovervågende, individualiseret og dydig bio-borger. I et sådan perspektiv bliver computerspillet Life Calculator et biopolitisk disciplineringsredskab, der gennem oplysning om sundhed, sygdom og risici har til formål at motivere den unge til at udvise ansvarlighed ved frivilligt og aktivt at tage vare på sin krop. Spillets konstruktion i form af valg og fravalg giver spilleren mulighed for at positionere sig som et ansvarligt subjekt, der er i stand til at disciplinere sin krop 'korrekt' ved at vælge 'rigtigt' og efter Hjerteforeningens anvisninger. Da kroppe imidlertid er bundet af sociale koder, aflæses kroppen ofte som et fysisk vidnesbyrd, der sladrer om subjektets sundhedstilstand og dennes evne til at disciplinere sig selv korrekt (Murray 78). Kroppe, som fejler i forsøget på at leve op til forestillingen om idealkroppen, der i en vestlig kapitalistisk kontekst reelt har betydet en maskulin, slank, potent, stærk, omstillingsparat, hårdfør, fleksibel, fri-for-handicap-og-altid-rask-krop (McRuer; Thomson), peges 
derfor let ud som afvigende og risikerer at blive det, man kan kalde for sundhedsmæssigt diskvalificeret. En sådan diskvalificering på baggrund af en kropslig afkodning, hævder fat-teoretiker Kathleen Lebesco, har længe haft store og negative konsekvenser for særligt den tykke krop, idet den som regel afføder automat-reaktionen: Fedt er usundt (Lebesco). Dette er i bedste fald en sandhed med modifikationer og i værste fald en velkonstrueret løgn, der ikke desto mindre betyder, at den tykke krop ofte anvendes som ultimativt visuelt symbol på en grænseoverskridende, afvigende, syg, amoralsk og u-disciplinerbar krop ude af stand til at tage vare på sig selv. LeBescos (og mange andre fat-teoretikeres) påstand om, at der ikke findes videnskabeligt bevis for at sige, at det at være tyk betyder, at man ikke også samtidig kan være sund, bakkes desuden op af en lang række forskere fra ganske mange forskellige videnskabelige discipliner - inklusive biomedicinske og folkesundhedsvidenskabelige vel at mærke. ${ }^{2}$

\section{AFFEKT}

Affektteoretiker Sara Ahmed anser det ikke for muligt på forhånd at adskille det sproglige fra det før-sproglige eller det fikserede fra det universelle - af den grund skelner hun heller ikke mellem prædiskursive affekter og sprogliggjorte følelser (Ahmed, The Promise of Happiness 230). Ahmeds forsøg på at dekonstruere dikotomien biologi/kultur er derfor heller ikke svære at spore i hendes analyser. Med begreber og inspiration hentet i performativitetsteori, psykoanalysen og marxistisk økonomisk teori foreslår Ahmed at behandle følelser som performative og relationelle størrelser, som cirkulerer mellem subjekter og som gennem denne cirkulation akkumuleres og skaber merværdi. Affekt findes med andre ord ikke inde i det

2 Se f.eks. Jan Wright, Michael Gard \& Paul F. Campos: The Obesity Epidemic: Science, Morality and Ideology (2005), Julie Guthman: Weighing in: obesity, food justice and the limits of capitalism (2011), Linda Bacon: Health at Every Size: The Surprising Truth About Your Weight (2010), Eric J. Oliver: Fat Politics. The Real Story behind America's Obesity Epidemic (2006) og i en dansk kontekst se f.eks. Birgit Petersson: "Fedme, slankekure og spiseforstyrrelser" i: Ugeskrift for læger, nr. 159; 46 (1997) og Marianne Raakilde Jespersen \& Verner Møller: "Det sygeliggjorte fedt" i antologien: Det diagnosticerede liv-sygdom uden grænser (2012). 
enkelte subjekt, men produceres som en effekt af denne cirkulation mellem subjekter. Ahmeds analyser går derfor i retning af, hvad følelser producerer og hvordan, samt hvilke interesserer en sådan produktion tjener, idet hun er langt mere nysgerrig på, hvad følelser igangsætter og performativt $g ø r$, end hvad følelser præcist er.

Et eksempel herpå er Ahmeds fænomenologiske analyse (og kritik) af lykke, der ellers ofte beskrives som en meget privat og iboende følelse, men som i stedet, ifølge Ahmed, bør forstås som et normativt orienteringspunkt, der guider og skubber subjekter i en bestemt og ensartet retning (Ahmed, The Promise of Happiness). Lykke kan desuden klistre bestemte kroppe sammen på specifikke måder og skabe forbindelse til bestemte objekter, der igennem denne glæde-tilskrivelse kommer til at repræsentere lykke. Det gode job, ægteskabet og kernefamilien er eksempler på sådanne lykkeobjekter, der indeholder løftet om lykke og fører os i bestemte retninger i livet.

Det er imidlertid ikke blot lykke, der har evnen til at klistre kroppe sammen i et affektivt fælleskab - også frygt, skyld og skam fungerer som effektivt klister, der får nogle kroppe og objekter til at flyde sammen, mens affektive grænser drages mellem andre på baggrund af denne differentiering. Med udgangspunkt i figuren 'terroristen' viser Ahmed, hvordan frygt, gennem associationer og sammenkædninger af det, som potentielt kunne være farligt, kan forstås som en metonymisk sidelæns bevægelse, der kan glide på tværs af subjekter og objekter og forvandle dem til frygtsomme tegn: “Frygt klistrer sig til de kroppe, [...] der 'kunne være' terrorister [...], til de kroppe, der læses som forbundne med terrorisme: Islam, araber, asiat, Østen osv." (Ahmed, The Cultural Politics of Emotion 79, min oversættelse). Frygten kan imidlertid også bevæge sig bagud ved at trække på objekter, tegn eller kroppe, der historisk set har været forbundet med det frygtede. Forestillingen om den sunde, viljestærke, slanke og raske krop kan uden tvivl læses som et udmærket og oplagt eksempel på et lykkeobjekt, som langt de fleste orienterer sig mod. Omvendt vil jeg gerne foreslå en læsning af den tykke og 'usunde' krop som en form for u-lykkeobjekt, der gennem en farlig og frygtsom fortælling om sygdom og død er med til at skabe og forme kropslig materialitet - en tolkningsmulighed jeg vil vende tilbage til. 


\section{UNGE}

I den føromtalte rapport Unge Hjerter, hvis resultater spillet Life Calculator er baseret på, synes problemets form tydeligt at relatere sig til den mængde af viden om hjertekarsygdomme, som de unge har, og mere specifikt: deres manglende ønske om mere viden:

Unge lever her og nu. De har svært ved at forestille sig, hvor galt det kan gå, hvis ikke de tager risikofaktorerne alvorligt. De forholder sig ikke direkte til, at de kan påvirke de determinanter, der har betydning for hjertekarsygdomme. De unge, der har haft hjertekarsygdomme tæt inde på livet via sygdomstilfælde i den nærmeste familie, ved selvfølgelig en del om hjertekarsygdomme, men selv mange af disse unge udtaler, at de dybest set ikke mener, at det er relevant viden for unge mennesker. Hjertekarsygdomme hører til langt ude i fremtiden, hvilket betyder, at viden og også erfaringen med sygdom i den nærmeste familie nedprioriteres. Flere unge ønsker dog, at viden om hjertekarsygdomme og risikofaktorer gøres relevant og interessant for dem. (Unge hjerter 42).

Hjerteforeningens forundersøgelse finder altså, at unge mennesker ikke bekymrer sig om fremtiden, hvorfor de heller ikke anser hjertekarsygdomme for at være et emne, der berører dem. Foruden de unges manglende ønske om at vide mere om hjertekarsygdomme, pegede forundersøgelsen desuden på, at de unge er "[...] trætte af at meget undervisning om sundhed er negativt ladet og ofte moraliserende" (Ibid. 41), ligesom de er trætte af måden, hvorpå især risiko, sygdomme og forholdsregler bliver formidlet (Ibid. 44). Hjerteforeningen konkluderer derfor, at det er nødvendigt at forbedre tilgangen til de unge ved at skabe mere vedkommende undervisningsmateriale, og det til trods for at forundersøgelsen samtidig slog fast, at:

[d]et er et generelt træk, at de unge er relativt sikre på deres vidensniveau. De stoler på, at de ved tilstrækkeligt og føler sig ydermere meget selvsikre i forhold til, at de helt sikkert ville være i stand til at finde yderligere information, hvis det skulle blive nødvendigt (Ibid. 38).

At de unge faktisk føler sig godt klædt på, hvad angår deres viden om sundhed, afvises altså, og i stedet etableres en ganske anden fortælling om den unge. Fortællingen kæder den 'manglende' interesse for fremtiden sammen med den 'manglende' viden om risikofaktorer: De unge kender kort 
sagt ikke til konsekvenserne af inaktivitet, fordi de ikke gider at engagere sig i sundhedsfremme, idet de "[...] dybest set ikke finder det relevant" (Ibid. 42), ligesom de ikke forstår værdien af mere viden herom (Ibid.). Konsekvensen af denne populære fortælling om ungdommelig dovenskab bliver, at en ung, som ikke er interesseret i Hjerteforeningens oplysninger om sundhed, diskursivt udgrænses som en doven ung, der ikke gider tage ansvar for sit helbred og sin krop. Hjerteforeningens forsøg på at skabe mere vedkommende undervisningsmateriale er da også tydeligt præget af forestillingen om den dovne unge: I spillets første møde med Life Calculators to værter, Christian og Jenny, spørger Christian: "Har du nogensinde tænkt på, hvor længe du kommer til at leve, altså, hvor gammel du bliver? Næh, vel? For hvem tænker på det. Der er jo længe til, og who cares?" (Ibid. 2). ${ }^{3}$ Spillets brug af unge værter og afslappede sprog vidner om Hjerteforeningens forsøg på at imødekomme ønsket om en ny og anderledes form for sundhedsfremmende undervisning. Den unge værts spørgsmål trækker samtidig på en anden populær kulturel forestilling om, at unge hverken frygter døden eller sågar nogensinde tænker over den. Den unge er altså ikke bange for døden, og det er også okay, lover værten og forbliver dermed helt i tråd med Hjerteforeningens formål om at "(...) motivere eleverne til at fremme egen sundhed, få viden om hjertekarsygdomme og blive mere bevidste om de risici en usund livsstil indebærer" (T.L. 1). Hjerteforeningen lover endvidere, at indholdet af undervisningsmaterialet vil være alsidigt og brugbart i mange sammenhænge, at der ikke vil forekomme moralske opsange i form af hverken "løftede pegefingre" eller "sure miner", og at det primære formål med undervisningsmaterialet er på en "anderledes og sjov måde" at finde ud, hvad sundhed er for en størrelse (T.E. 1). Sundhed fremstilles med andre ord som et rummeligt begreb, der er åben for forhandling - en fremstilling, der også i princippet understøttes af det valgte medie til formålet: et computerspil, der efter hvert scenarie tilbyder spilleren tre valgmuligheder og dermed lægger op til, at sundhed ikke er en entydig

3 Alle citater og uddrag vedrørende spillet Life Calculator er hentet i Hjerteforeningens eget manuskript og forkortes herefter med L.C. Forkortelserne T.L. og T.E. står for henholdsvis "Til læreren" og "Til eleven" og henviser til de to foldere, der beskriver spillets formål og indhold for lærer og elev. 
praksis, men kan gribes an på forskellig vis. Når Hjerteforeningen lægger op til, at sundhed bør forstås som et åbent begreb, er de samtidig helt på linje med WHO's mangeårige budskab om, at sundhed bør forstås som mere end blot fraværet af sygdom. Mens den snævre sundhedsforståelse altså har sit primære fokus på forebyggelse, lægger den brede sundhedsforståelse vægt på nødvendigheden af at fremme borgerens sundhedsressourcer på en lang række områder, der ikke direkte relaterer sig til sygdom (WHO 1986). Hjerteforeningen har dermed et ønske om at indskrive sig i den brede sundhedsforståelse, men det er, som vi skal se, besværligt at gøre i praksis, fordi foreningen har sine stærke rødder i den snævre biomedicinske forståelse af sundhed.

\section{SUNDHED}

Spillets vært Christian definerer aldrig begrebet sundhed for spilleren i detaljer, men slår i stedet fast, at "[...] der inde i os alle sammen [er] en lille Engel, som egentlig godt ved, hvad der er rigtigt, og som giver os dårlig samvittighed, når vi alligevel gør det forkerte"(L.C. 2). Med et snuptag bliver sundhed dermed gjort til en universel størrelse gemt dybt i os alle, men også til et spørgsmål om moral, idet Jenny tilføjer: "Men der findes også en lille Djævel inde i os, som er ligeglad med det hele, og som bare vil have det fedt" (Ibid.). Sat på spidsen bliver det at have det fedt nu til satans værk, og det ikke at foretage sig 'sunde' og 'rigtige' valg et tegn på ligegyldighed og ansvarsløshed. Således opstår sundhed som et simpelt samvittighedsspørgsmål, den enkelte selv må tage stilling til (men som alle allerede kender det korrekte svar på), og en eventuel 'usundhed' bliver dermed til et selvforskyldt og bevidst (forkert) valg. Spillet gør desuden brug af to figurer i form af en djævel og en engel. De to leder let tankerne i retning af en kristent konnoteret krop kendetegnet ved i sit indre at gemme på synd, skyld og et farligt begær, hvorfor kroppen historisk set har kaldt på konstant overvågning og kontrol (se f.eks. Bordo; Foucault, Biopolitikkens fødsel; Lebesco). I spillet Life Calculator er det imidlertid ikke en hvilken som helst krop, men specifikt en usund krop, der gennem sin forbindelse til uansvarlighed, dårlig moral og Djævlen selv bliver udpeget som problematisk og syndig: 
Christian: "Er du én af dem, der synes, at idræt i skolen eller at gå til sport eller fitness i fritiden er vildt kedeligt? Og bliver du forpustet bare ved tanken om at cykle til skole eller spille lidt fodbold med de andre i frikvarteret? Så er du én af dem, der risikerer at blive ramt af sygdomme lidt senere i livet."

Jenny: "Du ved sikkert godt, at dét, at man ikke rigtig bruger sin krop til noget, i sig selv gør én træt. Bevæger du dig ikke, bliver du endnu mere doven, og din kondi dropper ned under spærregrænsen."

Christian: "Når du ingen kondi har, så får du sværere ved at koncentrere dig og lære noget. Du sover også dårligere, du spiser mere usundt, og du risikerer at blive en omvandrende tudefrans, der går rundt og er depri eller brokker sig hele tiden. Kort sagt, du kommer ind i en ond cirkel ved ikke at motionere." (L.C. 7).

Konsekvenserne ved ikke at dyrke motion gøres i dialogen mellem de to værter ovenfor tydelige og konkrete: Uden den rette mængde motion risikerer den unge at blive syg senere i livet, men mere sikkert er det, at den unge vil opleve en række følgevirkninger, der på selvfølgelig vis tilskrives dårlig kondition som direkte (og eneste) årsag. Forestillingen om at sundhed i høj grad er et individuelt og personligt ansvar, betyder samtidig, at ansvaret for at afværge sygdomme, koncentrationsbesvær, dårlig nattesøvn og depression, som det var tilfældet i dialogen ovenfor, uden større besvær kan placeres hos den enkelte. Life Calculators tilgang til sundhed placerer imidlertid ikke blot ansvaret hos den enkelte, men hjælper også til at underbygge forestillingen om, at kroppen er en formbar størrelse, der kan modelleres og påvirkes efter lyst - selv social arv og konventionelle kønsroller fremstilles som mønstre, der uden videre kan brydes, når bare viljen er stærk nok:

Engel [om at dyrke motion]: "Djævlen har desværre også sørget for, at du tit bliver ligesom dine forældre. Og det er jo ret skidt, for der er altså mange forældre, der ikke dyrker andet motion til daglig, end at skifte gear i bilen. Men der er jo heldigvis ingen der siger, at du skal være ligesom dine forældre. Drenge er generelt mere aktive end piger, sådan er det bare. De spiller mere fodbold og har flere fysiske hobbies eller jobs. Og sådan fortsætter det, når man bliver voksen. Med mindre du gør noget ved det, selvfølgelig." (Ibid. 9).

Gennem spillets fortællinger om kroppen og dens formåen etableres et både kropsligt og sundhedsmæssigt ideal, der omvendt stiller de kroppe, som måtte fejle i forsøget på at leve op til dette ideal, en nedslående fremtid i sigte: 
Djævel [om spillerens valg af pizza fremfor rugbrødsmadder]: "Tillykke, du har valgt det fedeste [Det begynder at regne med hvinende grise. Djævel stikker til dem med sin trefork]. Kooom så da... Kooom til farmand, alle I små tykke grissebasser. Jeg elsker dem med lidt blæver på lårene, de er så nuttede. Og de dufter bare så dejligt, når man steger dem i deres eget fedt, mmm... Nå ja, så giver dårlig kost måske lidt sygdomme, når du bliver voksen. Men altså, hey. Tag det nu roligt. Det er jo først som voksen. Hvis du overhovedet bliver voksen. Det kan jo være du kradser af tidligt, og så kan du jo lige så godt æde noget mere nu. Pizza, burgere, lasagne, slik, mmm..." (Ibid. 4).

Det er muligt, at de tykke grise er ment som et eksempel på den form for 'usund' kost, som kan tage livet af spilleren, men det er nærliggende at pege på, at de hvinende grise på grund af deres plads netop her i fortællingen skal fungere som et billede på den 'usunde' krop, der dog ikke længere potentielt set er en hvilken som helst krop, men tværtimod har fået konkret fysisk form - den er blevet til en stor fed gris. Den visuelle fremstilling af de fede og skrigende grisekroppe med blæver på lårene, der dufter godt, når man steger dem i deres eget fedt, betyder at den fede (grise)krop smelter sammen med forestillingen om den 'usunde' og dovne krop, som allerede er etableret i spillet. En sammensmeltning, der ikke alene reducerer den 'usunde' og tykke krop til noget ikke-menneskeligt på kanten af det abjekte, men faktisk helt eliminerer den med løftet om en grum skæbne: "Hold stilen. Så ses vi snart, nede i Helvede." (Djævel, ibid. 5). Og netop den tykke krop bliver da også i kombination med den korte levetid gjort til den ultimative straf i spillet. Her er det Djævlen, som roser spilleren for ikke at ville tage med på en løbetur, når en ven inviterer:

\footnotetext{
"Sådan der, godt valgt. (...) OK, så bliver du fed og grim og slap og syg og dør lidt tidligt. Og det kan da godt være, du engang kommer til at gå til fysioterapeut hver dag, for at træne den eneste muskel, du har tilbage i din krop. Og ja ja, det kan da også godt være, du ikke selv kan komme op ad trapperne til din lejlighed om nogle år, fordi knoglerne i dine ben er lige så bløde som vingummi. Men hey! Det er sgu da NU den skal fyres af. Og hvis prisen er lidt piller, og nogle år mindre at leve i, og lidt sygdom på falderebet, jamen så er det da dét værd. Til helvede med dét, mand!" (Ibid. 9).
}

Inden for spillets egen logik er forkerte, uovervejede og dermed 'usunde' valg altså kausalt forbundet med det at være "fed og grim". Særligt det at blive fed fremstilles som særdeles u-ønskværdigt for piger, der risikerer 
ikke at kunne leve op til feminine skønheds- og kropsidealer: "Og man vil jo også gerne undgå at blive så fed, at man må gå i tøj, der ligner noget, der er lavet til en big mama." (Jenny om faren ved ikke at spise sundt, ibid. 5). Spillet tillægger kort sagt det at foretage sig 'usunde' valg en række konsekvenser, som ikke direkte relaterer sig til sundhed, men i stedet her har at gøre med den fede krops fejlslagne forsøg på at leve op til normative krops- og skønhedsidealer, der hviler tungt på antagelsen om, at en tyk krop nødvendigvis er en usund krop og helt sikkert ikke en begærlig eller smuk krop (Wann).

Opsummerende kan det siges, at den kategoriske diskvalificering af de dagligdagspraksisser og forestillinger om sundhed, der falder uden for Hjerteforeningens snævre definition af, hvad sundhed er, og hvordan sundhed kropsligt bør se ud, kommer i vejen for spillerens mulighed for mere selvstændigt at definere, hvad sundhed er eller kan være. Muligheden for at forholde sig anderledes til begrebet sundhed, end Hjerteforeningen gør det, besværliggøres simpelthen, idet dette kræver, at spilleren i stedet for at spejle sig i den 'sunde' krop omvendt må identificere sig med det eneste andet valg, spillet opstiller, nemlig den 'usunde' krop - og det er uden tvivl svært, når denne har antaget form af en fed (død) gris.

\section{TEGN OG KROPPE}

Med tanke på Ahmeds forklaring af, hvordan frygtsomme tegn kan bevæge sig både sidelæns og baglæns og herigennem klistre bestemte tegn, objekter og subjekter sammen, bliver den fede gris til en yderligere interessant figur. Hvis vi antager, at det som frygtes i spillet, er konsekvenserne af en 'usund livsstil', kan den fede (grise)krop læses som det eller den, der giver denne frygt en konkret fysisk krop. Frygten materialiserer sig med andre ord og tager form af en fed (grise)krop, der samtidig gennem en metonymisk og sidelæns bevægelse kædes sammen med og glider over og ind i spillets øvrige fortællinger om dovenskab, sygdom, viljeløshed og slutteligt: selvforskyldt død. Bevægelsen skaber dermed grænsedragninger mellem de kroppe og objekter, der på den ene side kan se sig fri af det frygtsomme tegn 'usundhed' (slanke kroppe, rugbrødsmadder, idrætstimer, løbesko), mens andre kroppe og objekter udpeges som problematiske og dermed 
frygtsomme (fede kroppe, chips, hvile, fjernsyn). Tegnet 'usundhed' kan dermed anvendes til at fremkalde en følelse af frygt (for døden) hos spilleren - en frygt som akkumuleres yderligere, hver gang det lykkes spilleren at undvige tegnet (ved at vælge 'rigtigt'). Frygten for 'usundhed' er med andre ord ikke fra starten til stede eller iboende i den fede døde gris, men opstår relationelt og i mødet med spilleren. I eksemplet nedenfor er spilleren gået med nogle klassekammerater ned i byen efter skole. På sin vej passerer han en lang række chips-spisende unge, og foran pizzeriaet skal han nu vælge mellem pizza eller rugbrødsmadder. I Hjerteforeningens manuskript er scenariet beskrevet således:

P er i tvivl. Ser prisskilt med "Tilbud: slice + lille cola $25 \mathrm{kr}$. ." P ser ind ad vinduet til pizzeriaet. Der sidder et overvægtigt og "usundt" par og spiser. Manden har en stor tatovering, kvinden mader deres lille barn med pizza. P afkræves svar. En dreng siger: "Hvad så, skal du med ind eller hvad?" (Ibid. 3).

Pizzeriaet bliver her til et lokkende rum indeholdende overvægtige og 'usun$d e^{\prime}$ kroppe i færd med en farlig praksis: at spise pizza. Og mens mandens store tatovering ikke direkte relaterer sig til usundhed, er den alligevel nævnt og glider derfor ind i og bliver til en del af billedet på den 'usunde' og dermed farlige krop. Når man spiller spillet, ser man imidlertid ikke kvinden made barnet, og mandens tatoveringer er heller ikke sådan lige at spotte. Ulykke-objektet i form af det 'usunde' par i vinduet er dog bibeholdt og fungerer dermed som et letgenkendeligt og frygtsomt tegn, som spilleren forventes at vende sig væk fra. Hvis spilleren således på dette tidspunkt i spillet skulle være i tvivl om sit valg, fungerer de lokkende og chips-spisende unge på vejen som farlige pejlemærker, der skubber spilleren i retning af pizzeriaet og de 'usunde' og tykke kroppe i vinduet som en tydelig advarsel og et frygtsomt tegn, der atter guider spilleren i den 'rigtige' retning: væk fra gruppepres og usundhed og hen imod den normative og 'sunde' krop.

Mens den 'usunde' krop i spillet altså fungerer som et nodalpunkt for død, sygdom og Helvede, knyttes den 'sunde' krop helt omvendt an til livet, blandt andet gennem spillets italesættelse af de fremtidige muligheder en sund krop gemmer på: "[...] hvis du vil have et langt liv i en krop, der kan tåle at du fyrer den af, at du rejser eller arbejder med lige hvad du har lyst til, så er det nu, du skal gøre noget ved dine vaner" (Ibid. 2). Sammenkædningen 
gør sundhed og usundhed til to let adskillelige størrelser, men også til et valg mellem liv og død. Selve muligheden for at vælge livet beror imidlertid på et ustabilt privilegium baseret på en konstant forhandling af, hvilke kroppe der overhovedet kan genkendes som levende - en genkendelse der afhænger af, at kroppen anerkendes som havende været levende $i$ det hele taget (Ahmed, The Cultural Politics of Emotion 56). De der ikke kan genkendes, forklarer Ahmed, risikerer at blive til som altid-allerede døde. Når den 'usunde' krop konstant og konsekvent i spillet skaber en automatisk kædereaktion, der forbinder usundhed med overvægt, død og Helvede, gives der således ikke plads til, at den 'usunde' krop kan anerkendes som en del af livet, og den 'usunde' krops mulighed for at blive genkendt som levende i det hele taget besværliggøres. Her er det f.eks. Engel om konsekvenserne ved ikke at spise sundt nok:

\footnotetext{
"Usund kost giver overvægt, som Djævlen så placerer på din mave, på dine hofter og i dit ansigt. Usund kost er f.eks. at du spiser for lidt frugt og grønt, og drikker for meget cola eller saft. Og hvis du nu også begyndte at spise slik eller is eller chips flere gange om ugen, så skulle han nok sørge for, du snart kommer ned til ham. Til tvungen tyrolermusik og stank af sved 24 timer i døgnet, adr..." (L.C. 4).
}

Mens spillet rummer rigelige eksempler som det ovenfor, hvori den 'usunde' og tykke krop ikke blot dømmes til døden, men også tildeles en plads i Helvede, er det interessant, i hvor ringe grad den 'sunde' krop omvendt sættes i forbindelse med døden. Fortællingen om den 'sunde' krops skæbne og død glimrer simpelthen ved sit fravær i spillet og er derved yderligere med til at styrke den sunde krops forbindelse til livet. Samtidig er det interessant at notere sig, hvordan det alene at være 'overvægtig' tilsyneladende er en synd, som er stor nok til at berettige spilleren en plads i Helvede.

\section{$\mathrm{D} \varnothing \mathrm{D}$}

Ahmed foreslår desuden at spørgsmålet om, hvilke kroppe der kan anerkendes som tilhørende livet, og hvilke der bliver til som altid-allerede døde, er sammenhængende med vores forståelse af sorg. Ahmed interesserer sig imidlertid for queer liv, dvs. subjekter som på forskellig vis indgår og lever i ikke-heteronormative relationer og praksisser, og hendes analyser 
relaterer sig derfor ikke (direkte) til hverken tykke eller 'usunde' kroppe. Hendes normkritiske analyser af affektive strukturer, frem for konkrete identitetskategorier, betyder ikke desto mindre, at hendes begreber bliver anvendelige i mange andre sammenhænge - for eksempel i denne artikels overvejelse af, hvordan forestillingen om den 'usunde' krop bliver til som et ulykke-objekt, der forsøger at guide og orientere spilleren i en bestemt retning (væk fra Helvede):

Queer liv må kunne anerkendes som liv for at kunne blive sørget over. På en måde er det derfor ikke, fordi queer liv eksisterer som 'usorgbare tab', men fordi queer tab ikke kan regnes som en form for tab i det hele taget, idet queer liv ikke anerkendes som liv, 'der kan mistes' (Ahmed, The Cultural Politics of Emotion 56, min oversættelse).

Risikoen for at blive til som altid-allerede død opstår i det øjeblik, en krop eller et liv ikke kan genkendes som kærlighedsværdig med positive investeringsmuligheder eller mere simpelt: For at noget kan forstås som værdifuldt og dermed sørgeligt at miste, må det have været elsket til at begynde med. Med denne pointe trækker Ahmed på Butler, der af flere omgange har forholdt sig til sorg og forestillingen om det tabte livs konstruktion og retfærdiggørelse (2004, 2010). I introduktionen til Frames of War beskriver Butler, hvordan:

[...] bestemte liv ikke kan opfattes som skadede eller tabte, hvis de ikke først opfattes som levende. Hvis visse liv ikke gælder som liv, eller fra starten ikke er tænkelige som liv inden for bestemte epistemologiske rammer, så leves eller tabes disse liv aldrig i den fulde betydning (1, min oversættelse).

Bestemte kroppe og til tider hele befolkningsgrupper risikerer ifølge Butler at blive udgrænset som undværlige og uværdige, når de gennem denne udgrænsning rammesættes som liv, der er ligegyldige og derfor altid-allerede tabte. Liv, der ikke lever op til normative forestillinger om, hvad et 'rigtig' liv er og indebærer, vil dermed ikke blive sørget over i døden, idet døden konstrueres som nødvendig og uundgåelig i forsøget på at beskytte livet for de subjekter, der omvendt kan genkendes som levende (Ibid. 30-31).

I Life Calculator er løftet om en lykkelig fremtid indlejret i fortællingen om den sunde krop på en måde, der gør de to uadskillelige. Lykken er med andre ord baseret på og betinget af det at have en krop fri af sygdom 
og særligt det frygtsomme tegn 'fedme'. Forbindelsen til det frie valg, det gode liv og til Engel gør derudover den 'sunde' krop letgenkendelig som både levende og som tilhørende livet mere grundlæggende. Fortællinger der knytter den 'sunde' krop sammen med død og sygdom er derfor tæt på umulige at finde i spillet. I stedet stilles den 'sunde' krop en lykkelig alderdom i sigte ovenpå et indholdsrigt og langt liv fri for sygdom, ligesom den generelt i spillet belønnes for sine valg med succes, glæde og lykke:

Engel: "Hvis du dyrker motion, så får du det bedre psykisk, du får det bedre socialt, og du får faktisk også nemmere ved at lære noget, i skolen f.eks. Derfor er det ikke helt forkert at sige, at motion gør dig klogere, mere populær blandt venner, og giver større selvværd" (L.C. 9).

Fremstillingen af den 'usunde' krop i form af en tyk, sygdomsbefængt og uansvarlig (grise)krop på vej mod Helvede lægger omvendt ikke op til, at den bør opfattes som en krop med krav på sorg, hvorfor spilleren heller ikke opfordres til at føle sympati med den, men til at forstå den som en krop der får, hvad den naturligt har fortjent. Med spillets forankring i en biomedicinsk forståelse af sundhed bliver rationalet, at den 'usunde' krop selv er ansvarlig for sin egen usundhed og sin position som, hvis ikke altid-allerede død så i hvert fald altid-allerede syg og med et ben plantet solidt i graven:

Engel: "Det værste er næsten, at rygerne ikke bare skal dø af at ryge, men de er tit også syge de sidste 10 år før de dør. De har svært ved at få vejret, de hoster konstant, de kommer på hospitalet, deres lunger holder op med at fungere, de kan ingenting. Et rygerliv er et kort og dårligt liv, sådan er det bare." (Ibid. 13).

En sådan position selvfølgeliggør ikke blot den 'usunde' krops død, men kræver den faktisk gennem spillets etablering af fortællingen om den 'usunde' krop, der grundet sine syndige og amoralske valg naturligt hører til i Helvede blandt andre syndige kroppe, der enten ikke kan eller vil leve op til normative sundheds- og kropsidealer.

\section{AFSLUTNINGSVIS}

At stå uden for det fælleskab af kroppe, der kan genkendes som levende, er ikke en ønskværdig position for nogen - og når skylden for denne position 
samtidig rettes mod den 'usunde' og dermed altid-allerede døde krop, ja så bliver den samtidig til selvforskyldt bærer af sin egen eksklusion og udgrænsning. Omvendt bliver den dydige bioborger gennem levendegørende handlinger, som det at gå til fitness, spise sundt og undlade at ryge, til en krop som er værd at investere kærlighed i. Frygten for ikke længere at kunne leve op til disse idealer lurer dog altid i baggrunden, og kroppen står altid klar til at sladre. Med denne artikel har jeg forsøgt at vise, hvordan frygten for ikke at kunne kropsliggøre sådanne sundhedsidealer kan forstås som et ganske effektivt biopolitisk redskab, der gennem frygten for at fejle (og blive 'usund'), ikke alene er med til at opretholde normative kropslige og sundhedsmæssige idealer, men også aktivt skaber dem gennem et affektivt narrativ om kroppen. Når sundhed fremstilles som et spørgsmål om moral og vilje, bliver det således den 'usunde' krops eget ansvar at slippe af med tegnet 'usundhed' (i dette tilfælde den tykke krop) og dermed undslippe døden, idet fortællingen om en lykkelig og levedygtig tyk krop fra starten er umuliggjort af det frygtsomme tegn 'usundhed'.

Min læsning af Life Calculator viser altså, at spillet må forstås som et både affekt- og effektfuldt narrativ, der skaber tydelige skel mellem kroppe og på baggrund heraf bliver til et disciplinerende biopolitisk redskab - eller måske rettere: et godt eksempel på den dødspolitik, som biomagten også indebærer.

På falderebet har jeg lyst til at rette blikket mod crip-teoretikeren Robert McRuer og hans pointe om, at kroppens kunnen og formåen aldrig er "fri", men i virkeligheden en tvungen kunnen (8). At være en del af et neoliberalt og kapitalistisk samfund giver på den ene side subjektet ret til at sælge sin arbejdskraft til hvem hun vil, forklarer McRuer, men subjektets tilværelse er samtidig betinget af, at hun trods alt sælger den til nogen. I et neoliberalt samfund dækker det, der synes som et frit valg altså over det faktum, at man i realiteten er tvunget til at have en krop, der kan arbejde: "Ligesom med tvungen heteroseksualitet fungerer tvungen able-bodiedness ved, med et tilsyneladende valg, at dække over et system, hvori der rent faktisk ikke er noget valg." (Ibid., min oversættelse) Det er netop McRuers forsøg på at forstyrre denne idealisering af en altid rask, potent, omstillingsparat og fleksibel krop, der får mig til at tænke på Life Calculators konstruktion af samme. Den altid sunde, raske og levedygtige 
krop fremstilles som et opnåeligt ideal tilgængeligt for alle, der er villige til at disciplinere deres krop efter Hjerteforeningens anvisninger. Samtidig lover Hjerteforeningen, at spillet ikke vil indeholde løftede pegefingre underforstået er spilleren altså i sin gode ret til at fravælge den form for sundhed, som Hjerteforeningen opstiller som ønskværdig. Konsekvensen ved ikke at vælge 'rigtigt' er dog reelt, at spilleren må afskrive sig eventuelle forhåbninger om at blive genkendt som levende, lykkelig og sund, og spillet kan dermed siges at forsøge at dække over det faktum, at sundhed ikke reelt er et frit valg, men i stedet en tvungen gøren.

Camilla Bruun Eriksen er ph.d.-stipendiat ved Institut for Kulturvidenskaber, Syddansk Universitet (Odense). Artiklen er en del af en ph.d. afhandling om populærkulturelle fortællinger om den tykke krop.

\section{HELL HOLDS A SPECIAL PLACE FOR LAZY KIDS}

This article takes a closer look at the educational computer game Life Calculator (2010) and its attempts to inform young people about health risks and it argues that the game becomes a biopolitical and disciplinary tool. Drawing on the work of Foucault, the article claims that specific bodies are made (im)possible through the game's strong narrative about Hell, death and health. The article will show how this narrative helps create 'healthy' and 'liveable' subject positions (for some) while understandings (of what health is or could be) that differ from the game's view are stigmatized in the process. Inspired also by Sara Ahmed and her claim that emotions are cultural practices that hold affective power and organize our modes of life, this article is interested in the ways the 'healthy' body is understood as tied to life and therefore gets to count as life. The article concludes that health logics are organized and negotiated through a fearsome narrative about the 'fat' and 'unhealthy' body.

Keywords: affect, fat, health, death, biopolitics, computer games 


\section{LITTERATUR}

Ahmed, Sara. The Promise of Happiness. Duke University Press: Durham \& London, 2010. Ahmed, Sara. The Cultural Politics of Emotion. Edinburgh University Press:

Edinburgh, 2004.

Bordo, Susan. Unbearable Weight: Feminism, Western Culture, and the Body. University of California Press: Berkeley \& Los Angeles, 2004.

Butler, Judith. Precarious Life. The Power of Mourning and Violence. Verso: London \& New York, 2004.

Butler, Judith. Frames of War. Verso: London \& New York, 2010.

Foucault, Michel. Biopolitikkens Fødsel. Forelæsninger på Collége de France 1978-1979. Hans Reitzels Forlag. København, 2009.

Foucault, Michel. Viljen til Viden: Seksualitetens historie 1. Det Lille Forlag: Helsingør, 2011.

From, Ditte-Marie. De sunde overvægtige børn. Sundhedspædagogiske potentialer i arbejdet med overvægtige børn. Ph.d.-afhandling, Institut for Psykologi og Uddannelsesforskning, Roskilde Universitet, 2012.

Land, Birgit \& Pedersen Bransholm, Kirsten. "Sundhed - et individuelt eller samfundsmæssigt

ansvar?" i: Social Kritik, nr. 122, 2010.

LeBesco, Kathleen. Revolting Bodies? The Struggle to Redefine Fat Identity. University of Massachusetts Press: Amherst and Boston, 2004.

Lupton, Deborah. Medicine as Culture. SAGE Publications: London, 2003.

McRuer, Robert. Crip Theory - Cultural Signs of Querness and Disability. New York

University Press: New York \& London, 2006.

Minkler, Meredith. "Personal Responsibility for Health? A Review of the Arguments and the Evidence at Century's End" i: Health Education \& Behavior. Vol. 26 no. 1, 1999.

Murray, Samantha. "Marked as 'Pathological': 'Fat' Bodies as Virtual Confessors". Biopolitics and the 'Obesity Epidemic'. Governing Bodies. Red. Jan Wright \& Valerie Harwood, Routledge: New York, 2009.

Richardson, Niall \& Locks, Adam. Body Studies. Routledge: London \& New York, 2014.

Rose, Nikolas. Livets politik - Biomedicin, magt og subjektivitet $i$ det 21. Århundrede. Dansk Psykologisk Forlag: København, 2009.

Thomson, Rosemarie Garland. Extraordinary Bodies: Figuring Physical Disability in American Culture and Literatur. Colombia University Press: New York, 1997.

Weblogs:

Life Calculator, Web. 20. oktober 2015. http://www.hjerteforeningen.dk/lifecalculator/\#. Unge Hjerter. Afdækning af unges viden og kompetencer inden for området sundhed og hjertekarsygdomme, Web. 20. oktober 2015. http://pure.au.dk/portal/da/projects/unge-hjerter-afdaekning-af-unges-viden-og-kompetencer-inden-for-omraadet-sundhed-og-hjertekarsygdomme\%28ff34e1ee-5be9-4630-bo73-4217f25a876e\%29.html. WHO 1986, Web. 20. oktober 2015. http://www.who.int/healthpromotion/conferences/ previous/ottawa/en/. 
82 KULTUR \& KLASSE * $120 * 2015$ (U)SUNDE KROPPE 